$\angle$ Research Square

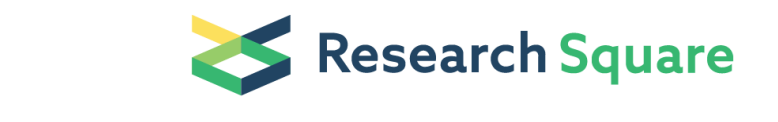

Preprints are preliminary reports that have not undergone peer review.

They should not be considered conclusive, used to inform clinical practice, or referenced by the media as validated information.

\title{
Use of rare earth elements as tracers for soil-plant transfer of trace elements
}

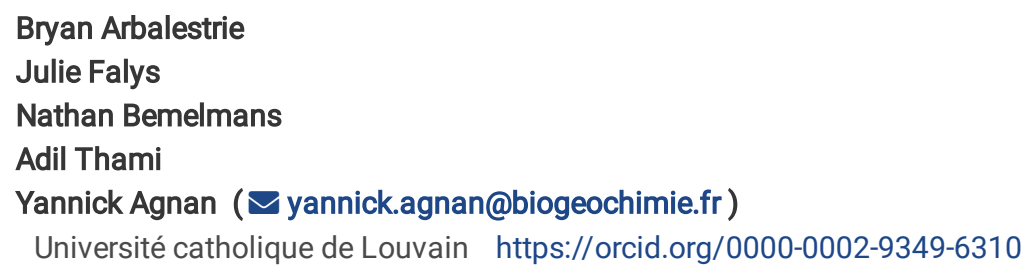

Bryan Arbalestrie

Julie Falys

Nathan Bemelmans

Adil Thami

Yannick Agnan ( $\square$ yannick.agnan@biogeochimie.fr)

Université catholique de Louvain https://orcid.org/0000-0002-9349-6310

\section{Research Article}

Keywords: Rare earth elements, trace elements, soil, plant, soil solution, transfer

Posted Date: February 7th, 2022

DOI: https://doi.org/10.21203/rs.3.rs-1319944/v1

License: (c) (i) This work is licensed under a Creative Commons Attribution 4.0 International License. Read Full License 


\section{Abstract}

Purpose Transfer of trace elements from soil to plant is a corner stone for risk assessment. Rare earth elements (REE) are frequently used as geochemical tracers for element transfer to plant. In this study, we evaluated biogeochemical behaviors of trace elements and REE in the soilplant continuum to assess to what extend the REE monitoring allows identifying preferential pathway from soil to plant. Methods We quantified 11 trace elements and 14 REE in soil, root, shoot, soil solution, and soil water-extract samples of an intercropping cover crop. Evaluation of the element mobility was performed using both soil extractability and transfer factors. Results Results showed distinct soil-plant transfer of trace elements according to their biological roles or substitution potential. Soil, root, and shoot REE patterns were similar, indicating a large influence of soil REE composition on plant one. Compared to light REE (LREE), heavy REE (HREE) were more extractable and thus transferred to plants. We also observed differences in Ce and Eu behavior concerning soil extractability and transfer from root to shoot. Conclusion Soil solution and soil water-extract samples are not chemically representative of the fraction that can be uptaken by plants. However, LREE/HREE and Ce/Eu ratios in soil solution and soil water-extract samples can be used as indicators of environmental conditions.

\section{Introduction}

Trace elements, whose concentration is $<0.1 \%$ in the continental crust, include metals ( $\mathrm{Cd}, \mathrm{Cu}, \mathrm{Mn}, \mathrm{Ti}, \mathrm{V}, \mathrm{Zn} \ldots$...) and metalloids (As, Sb...). All of them may induce potentially harmful effects on human and ecosystem health according to the concentration. Their cycling in the environment depends on both their sources and the conditions of natural compartments (Rauch and Pacyna 2009; Kabata-Pendias 2010). In agricultural soils, they are originated from (He et al. 2005): (1) natural sources resulting from parent material alteration, whose flux depends on the parent material composition; and (2) various anthropogenic sources, such as organic amendments, fertilizers, and pesticides. Transfer of trace elements from soil to plant, and their recycling by vegetation, involve multiple processes that depend on pedological, biological, or climatic factors, all of them resulting in changes of element speciation. For instance, the main factors affecting the trace element availability are soil pH, redox potential, concentration of mineral and organic constituents (both clays and organic matter control the cation exchange capacity), and "aging" of added elements promoting the element scavenging over time (Antoniadis et al. 2017). Moreover, each element behaves differently from soil to plant according to its geochemical properties: element can be absorbed either by passive (diffusion of ions from the soil solution into the root endodermis, e.g., $\mathrm{Ni}$ and $\mathrm{Pb}$ ) or active (against a chemical gradient requiring metabolic energy, e.g., $\mathrm{Cu}, \mathrm{Mo}$, and $\mathrm{Zn}$ ) pathway (Kabata-Pendias 2010). Yet, environmental and human health concerns depend on the mobility and phytoavailability of these trace elements in the soil-plant system (Kabata-Pendias 2004). To understand their dynamics in the environment and assess their potential risk, it is recommended to use geochemical tracers for soil-plant transfer.

Rare earth elements (REE), also called lanthanides, include 14 natural trace elements split into light REE (LREE, from La to Eu) and heavy REE (HREE, from Gd to Lu). Sometimes, medium REE (MREE, from Pr or Nd to Dy or Ho) can be considered as an intermediate class. As for other trace elements, environmental variables, such as soil pH and redox potential, play an important role in REE mobility, and thus bioavailability (Cao et al. 2001). Rare earth elements are characterized by a similar electronic configuration, including a large ionic radius, a trivalent oxidation state, and a lower electronegativity than those of the transition elements (Henderson 1984; Laveuf and Cornu 2009). However, REE behave differently according to their atomic number: for example, LREE are more soluble and less complexed than HREE (Cantrell and Byrne 1987), promoting soil migration or root uptake of LREE, and thus, increasing LREE/HREE ratio along the soil profile. This singular behavior can be related to preferential scavenging of HREE by Fe-oxyhydroxides (Brioschi et al. 2013; Martinez et al. 2018). Moreover, among REE, Ce and Eu present an extra valence $\left(\mathrm{Ce}^{4+}\right.$ and $\mathrm{Eu}^{2+}$, respectively) that generates positive or negative anomalies after fractionation processes. For example, surface waters are characterized by strong negative $\mathrm{Ce}$ anomaly resulting from Ce depletion produced by the oxidation of $\mathrm{Ce}^{3+}$ to $\mathrm{Ce}^{4+}$ (Leybourne et al. 2000). On the other hand, reduction of $\mathrm{Eu}\left(\mathrm{Eu}^{3+}\right.$ to $\left.\mathrm{Eu}^{2+}\right)$ with decreasing redox potential (e.g., in the rhizosphere) improves the Eu mobility in soils (Krzciuk and Gałuszka 2020). Thus, REE are helpful tracers for various environmental purposes in geochemistry (Aubert et al. 2001; Liang et al. 2005; Laveuf and Cornu 2009).

Rare earth elements are investigated in different natural compartments and landscapes, such as atmospheric deposition (Sholkovitz et al. 1993; Iwashita et al. 2011), surface waters (Stille et al. 2006; Pourret et al. 2008), soils (Laveuf et al. 2008; Ramos et al. 2016), wetlands (Davranche et al. 2011, 2015), and plants (Tyler 2004; Brioschi et al. 2013). In the Earth's crust, the average REE abundance ranges from $0.3 \mathrm{mg} \mathrm{kg}^{-1}$ in Tm to $63 \mathrm{mg} \mathrm{kg}^{-1}$ in Ce (Rudnick and Gao 2014). In European soils, REE concentrations are in the same range, from $0.312 \mathrm{mg} \mathrm{kg}^{-1}$ in Tm to $52.2 \mathrm{mg}$ $\mathrm{kg}^{-1}$ in $\mathrm{Ce}$ (Fedele et al. 2008), demonstrating a large lithologic origin. Heterogeneity in REE concentrations, however, occurs in natural soils according to the bedrock mineral composition (Hu et al. 2006). Root uptake is the key mechanism for soil-plant transfer of REE and this process largely depends on plant physiology and element speciation. Despite the low soil-plant transfer of REE, some differences between them occur according to the atomic number: LREE are more transferable from soil to plant than HREE (Tyler 2004). Moreover, root exudates (amino acids, phytosiderophore...) interfere in the soil-plant transfer acting as chemical transporters of elements (Kabata-Pendias 2010). Due to complexation with Fe-oxyhydroxides, REE uptake from plants may be related to phytosiderophore production in the rhizosphere (Martinez et al. 2018). Then, transfer of REE from roots to shoots can follow two different routes: apoplastic (through the cell wall) or symplastic (through the cytoplasm). Both routes are generally interrupted by the Casparian strip, which modulates the transfer of specific ions to the aerial parts of the plant (Brioschi 
et al. 2013). However, LREE seem to be preferentially translocated from roots to shoots that generates an increase of LREE/HREE ratio in shoots compared to roots.

Thus, REE constitute interesting geochemical tracers to characterize the trace element transfer pathway from soil to plant (Liang et al. 2008; Laveuf and Cornu 2009). In this context, the objective of this study was to assess to what extent the REE monitoring allows identifying preferential pathway in the soil-plant system through the different compartments (soil, water, plant). For this purpose, we conjointly analyzed trace elements and REE concentrations and compared geochemical signatures in the soil-plant continuum of an intercropping cover crop, including soil, root, shoot, soil solution, and soil water-extract samples, and evaluated the element mobility using both soil extractability and transfer factors.

\section{Materials And Methods}

\subsection{Study area}

The study was carried out from September 2020 to March 2021 in an intercropping cover crop of ca. $24000 \mathrm{~m}^{2}$ (340 m $\left.\times 70 \mathrm{~m}\right)$ located at the centre Alphonse de Marbaix, Corroy-le-Grand, Belgium (UCLouvain experimental farm, $135 \mathrm{~m}$ a.s.l). The field was covered by Persian clover (Trifolium resupinatum) and sorghum (Sorghum bicolor $\times$ Sorghum sudanense) sown at the end of August 2020, as well as bean (Vicia faba) and spelt (Triticum spelta) regrowth from the previous crop. The study area is characterized by a temperate oceanic climate with a mean annual air temperature of $10.6^{\circ} \mathrm{C}$ and a mean annual precipitation of $820 \mathrm{~mm}$ (www.meteo.be). It is located on aeolian loess deposit formation and characterized by silty and well-drained soils, typical agricultural soils found in northern Wallonia. Average soil $\mathrm{pH}_{\mathrm{KCl}}$ reached 6.2 and 6.1 at $0-30$ and $30-50 \mathrm{~cm}$ depth, respectively, and soil carbon content, 1.2 and $0.5 \%$, respectively.

\subsection{Sampling procedure}

For representativeness purpose, soil, plant, and soil solution samples were collected within three distinct sub-areas corresponding to a circle of $7 \mathrm{~m}$ in diameter. The distance between each sub-area is ca. $50 \mathrm{~m}$. In each sub-area, a composite soil sample, corresponding to a total of eight sub-sampling, was collected at two depths $(0-30 \mathrm{~cm}$ and $30-50 \mathrm{~cm})$ using an auger.

Soil solution samples were collected in each sub-area using 5 rhizons (19.21.01F, Rhizosphere, Wageningen, The Netherlands) installed vertically in the top $10 \mathrm{~cm}$ of the soil at the circle periphery. The rhizons consisted of a 10-cm long hydrophilic polyether sulphone membrane with a $0.15-$ $\mu \mathrm{m}$ porosity. Sampling was performed using a $60-\mathrm{mL}$ polypropylene syringe (BD Plastipak luer lock). The five collected samples were merged into a single composite soil solution sample per sub-area to obtain sufficient volume for chemical analysis. Soil solutions were collected five times during the experiment, approximately each month (21 Oct. 2020, 16 Nov. 2020, 15 Dec. 2020, 14 Jan. 2021, and 4 Feb. 2021).

Plant samples considered three different species: bean (Vicia faba), Persian clover (Trifolium resupinatum), and spelt (Triticum spelta). Several specimens were collected in each sub-area (within $5 \mathrm{~m}$ around the circle center point), considering both roots and shoots, and stored in plastic bags. Plant sampling were performed three times during the experiment following the plant growth stages: early (16 Oct. 2020$)$, middle (15 Dec. 2020), and late (4 Feb. 2021).

Finally, earthworms were sampled on 4 Feb. 2021 by collecting on average 18 specimens per sub-area in the first $10 \mathrm{~cm}$ depth of soil. To complete the data set, a single sample of unfiltered fresh deposited snow was directly collected on plant leaves on 14 Jan. 2021.

\subsection{Sample preparation}

Collected soil samples were dried $\left(25^{\circ} \mathrm{C}\right.$ in a drying room for seven days), sieved (<2 mm), and ground using a soil grinder (Vibratory Disc Mill RS 200, Retsch, Haan, Germany). For plant material, samples were gently cleaned with distilled water to remove as much soil residue as possible and dried in a ventilated oven at room temperature. Shoots were separated from roots before grinding (Cyclotec 1093 Sample Mill, Foss A/S, Hillerød, Denmark). Earthworm samples were washed with distilled water and left on wet paper in Petri dishes for 12 days to evacuate their digestive tract content. Then, they were frozen in a freezer at $-18^{\circ} \mathrm{C}$, dried in an oven at $40{ }^{\circ} \mathrm{C}$, and ground in a mortar with liquid nitrogen.

Approximately $100 \mathrm{mg}$ of ground soil, plant, and earthworm samples were digested in a Savillex (Teflon bottle) in an ISO 6 cleanroom (Earth and Life Institute, UCLouvain, Belgium) using a mixture of suprapure acids $\left(\mathrm{HNO}_{3}, \mathrm{HCl}\right.$, and $\mathrm{HF}$ ) and $\mathrm{H}_{2} \mathrm{O}_{2}$ in a four-step procedure: (1) $\mathrm{HNO} / 3 \mathrm{HF}$, (2) $\mathrm{H}_{2} \mathrm{O}_{2}$, (3) $\mathrm{HNO}_{3} / \mathrm{HCl}$, and (4) $\mathrm{HNO}_{3}$. Heating plate temperature was fixed of $90{ }^{\circ} \mathrm{C}$ for heating steps (at least for $24 \mathrm{~h}$ ) and $40{ }^{\circ} \mathrm{C}$ for evaporation steps. Finally, samples were preserved in $2 \% \mathrm{HNO}_{3}$ solutions before ICP-MS analysis. All cleaning and analytical procedures used high purity Milli-Q water (18.2 M $\Omega \mathrm{cm})$.

A water extraction was performed on $2 \mathrm{~g}$ of soil samples for each sub-area and depth by adding $20 \mathrm{~mL}$ of milli-Q water. The samples were stirred for $2 \mathrm{~h}$ and then centrifuged at $4000 \mathrm{rpm}$ for $25 \mathrm{~min}$. Then, samples were filtered, first with 20- $\mu \mathrm{m}$ Whatman filters, and then with $0.2-\mu \mathrm{m}$ GHP 
Acrodisc (PSF and nylon, Pall). All liquid samples (soil solutions, soil water-extracts, and snow) were acidified to reach $2 \% \mathrm{HNO}_{3}$ before ICP-MS analysis.

\subsection{Chemical analyses}

A set of 11 trace elements (Ba, Cd, Co, Cr, Cu, Mn, Pb, Sr, Ti, V, and Zn) and 14 REE (La, Ce, Pr, Nd, Sm, Eu, Gd, Tb, Dy, Ho, Er, Tm, Yb, and Lu) was quantified using an ICP-MS (iCAP Q ICP-MS, Thermo Fischer Scientific, Waltham, MA, USA) at the Earth and Life Institute analytical platform (UCLouvain, Belgium). Common interferences were automatically corrected after analytical tests (Pourret et al. 2021). An internal standard (Ru, In, and Re) was used in each sample for mass deviation correction. In order to evaluate the performance of the procedure for organic and mineral matrices, two certified materials well characterized for REE concentrations (lichen IAEA-336 and basalt BHVO-2, respectively) were added for each series. The average recovery $\left(C_{\text {measured }} / C_{\text {certified }} \times 100\right)$ calculated for each analyte was approximately: $(1) 90 \pm 5 \%$ for the lichen IAEA-336,

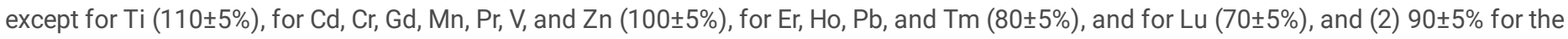

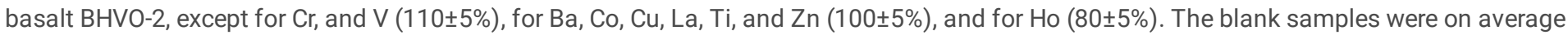
0.005-252 $\mathrm{ng} \mathrm{L}^{-1}$ according to the element (Er to Ti, respectively), which represented $<1 \%$ of the sample concentration analyzed (except for Cd and $\mathrm{Ti}$ with $2 \%$ ), indicating an absence of contamination during the digestion procedure. Limits of detection were estimated to $<1 \mathrm{ng} \mathrm{kg}^{-1}$, except for $\mathrm{Cr}$, $\mathrm{Cu}, \mathrm{Mn}, \mathrm{Pb}, \mathrm{Sr}$, and $\mathrm{V}\left(<0.01 \mu \mathrm{g} \mathrm{kg}^{-1}\right)$, for Ba and $\mathrm{Zn}\left(<0.1 \mu \mathrm{g} \mathrm{kg}{ }^{-1}\right)$, and for $\mathrm{Ti}\left(<1 \mu \mathrm{kg}^{-1}\right)$.

\subsection{Data processing and statistical analyses}

To evaluate the transfer of trace elements between compartments, two indices were considered (Adriano 2001, Marchiol et al. 2004, Antoniadis et al. 2017): the transfer factor from soil to plant $\left(\mathrm{TF}_{\text {soil-plant }}\right)$ and the transfer factor from root to shoot $\left(\mathrm{TF}_{\text {root-shoot }}\right)$, calculated as follows:

$$
\begin{aligned}
& \mathrm{TF}_{\text {soil-plant }}=\frac{\mathrm{C}_{\text {shoot }}}{\mathrm{C}_{\text {soil }}} \\
& \mathrm{TF}_{\text {root-shoot }}=\frac{\mathrm{C}_{\text {shoot }}}{\mathrm{C}_{\text {root }}}
\end{aligned}
$$

with $\mathrm{C}_{\text {shoot }}, \mathrm{C}_{\text {root }}$, and $\mathrm{C}_{\text {soil }}$, the element concentrations in shoot, root, and soil, respectively.

Rare earth elements were presented as normalized profiles as done in the literature using: (1) UCC (upper continental crust, Rudnick and Gao 2014) reference material for soil samples (Cidu et al. 2013), (2) soil (0-30 cm depth) for soil water-extract (except for soil water-extract samples from 30-50 cm depth normalized by 30-50 cm soil depth), plant, soil solution, and earthworm samples (Brioschi et al. 2013) for a better comparison, and (3) snow samples for soil solution samples to evaluate the potential atmospheric input. To facilitate comparisons, all graphs were performed using the same log scale. Several REE indices frequently used in the literature were calculated based on measured concentrations (Wyttenbach et al. 1998a, Miao et al. 2008, Agnan et al. 2014): Ce, Eu, Tb, and Yb anomalies calculated by dividing the normalized value by the expected value (obtained by averaging the values of the elements immediately prior and after), and LREE/HREE ratio using the following normalized concentration ratio:

$$
\frac{\mathrm{LREE}}{\mathrm{HREE}}=\frac{(\mathrm{La}+\mathrm{Ce}+\mathrm{Pr}+\mathrm{Nd}+\mathrm{Sm}+\mathrm{Eu}) / 6}{(\mathrm{Gd}+\mathrm{Tb}+\mathrm{Dy}+\mathrm{Ho}+\mathrm{Er}+\mathrm{Tm}+\mathrm{Yb}+\mathrm{Lu}) / 8}
$$

Statistical tests were performed using R 4.0.4 (R Core Team 2021). Statistically significant differences were tested using the non-parametric Kruskal-Wallis test $(a=0.05)$ and the post-hoc Dunn test $(a=0.05)$ with the dunn.test package (Dinno 2017). Principal component analyses (PCA) were performed to identify the relationships between elements using FactoMineR and factoextra packages (Lê et al. 2008) on element concentrations after centered log-ratio transformation (clr function) using rgr package (Garrett 2013). Scatter plots were performed using the ggplot2 package (Wickham 2016).

\section{Results}

\subsection{Trace elements}

\subsubsection{Trace element concentrations}

Trace element concentrations were measured in various compartments (Table 1 and Table S1). Higher values were reported in soil samples, ranging from $\mathrm{Cd}$ ( 0.33 and $0.18 \mathrm{mg} \mathrm{kg}^{-1}$ at $0-30$ and $30-50 \mathrm{~cm}$ depth, respectively) to $\mathrm{Ti}$ (2030 and $2606 \mathrm{mg} \mathrm{kg}^{-1}$, respectively). In plant 
samples, trace elements were, on average, 3-times more concentrated in roots compared to shoots and still ranged from Cd (on average 0.41 in roots and $0.08 \mathrm{mg} \mathrm{kg}^{-1}$ in shoots) to $\mathrm{Ti}$ (301 and $114 \mathrm{mg} \mathrm{kg}^{-1}$, respectively). Trace element concentrations in roots generally increased from Trifolium resupinatum to Triticum spelta (except for $\mathrm{Cd}, \mathrm{Cr}, \mathrm{Cu}, \mathrm{Sr}$, and $\mathrm{Zn}$ ), while those measured in shoots generally increased from Vicia faba to Triticum spelta (except for $\mathrm{Cu}, \mathrm{Sr}$, and $\mathrm{Zn}$ ). In soil water-extract samples, concentrations increased from $\mathrm{Cd}\left(0.08\right.$ and $0.04 \mu \mathrm{g} \mathrm{kg}{ }^{-1}$ at $0-30$ and 30-50 cm depth, respectively) to $\mathrm{Ba}$ (136 and $62.3 \mathrm{\mu g} \mathrm{kg}^{-1}$, respectively). The soil water-extract fraction represented from 0.01 to $1.9 \%$ of the total $0-30 \mathrm{~cm}$ depth soil concentrations (increasing in the following order: $\mathrm{Ti}, \mathrm{Cr}, \mathrm{Co}, \mathrm{Mn}, \mathrm{Pb}, \mathrm{V}, \mathrm{Cd}, \mathrm{Sr}, \mathrm{Ba}, \mathrm{Cu}, \mathrm{and} \mathrm{Zn}$ ) and from 0.02 to $0.75 \%$ o for the 30-50 cm depth (increasing in the following order: $\mathrm{Ti}, \mathrm{Co}, \mathrm{Cr}, \mathrm{Mn}, \mathrm{Pb}, \mathrm{V}, \mathrm{Cd}, \mathrm{Ba}, \mathrm{Sr}, \mathrm{Cu}$, and $\mathrm{Zn}$ ). Concentrations in soil solutions ranged from $\mathrm{Cd}\left(0.02 \mu \mathrm{g} \mathrm{L}^{-1}\right)$ to $\mathrm{Zn}\left(160 \mu \mathrm{g} \mathrm{L}^{-1}\right)$ with noticeable heterogeneity between sampling dates (average relative standard deviation of $\left.47 \%\right)$. The soil solution/soil ratios showed the same order of elements as observed for element extractability. In general, soil solutions were more concentrated than snow sample, except for $\mathrm{Cd}, \mathrm{Cr}, \mathrm{Mn}, \mathrm{Pb}$, and Ti. Finally, earthworm samples showed lower concentrations than shoots, except for Cd, Co, and Zn.

\subsubsection{Trace element transfer factors}

Two transfer factors were calculated for each trace element and each sampling date, including soil to plant (i.e., soil to shoot, $\mathrm{TF}_{\text {soil-plant }}$ ) and root to shoot $\left(\mathrm{TF}_{\text {root-shoot }}\right.$ ) transfer factors. The three species collected were considered: Trifolium resupinatum (Figure 1), Vicia faba (Figure S1A-B), and Triticum spelta (Figure S1C-D). The transfer of trace elements from soil to Trifolium resupinatum showed significant differences between elements, including $\mathrm{Ti}, \mathrm{V}, \mathrm{Pb}, \mathrm{Co}$, and $\mathrm{Cr}$ with the minimum values $\left(\mathrm{TF}_{\text {soil-plant }}<0.05\right)$ and $\mathrm{Zn}$, Sr, and $\mathrm{Cu}$ with the maximum values $\left(\mathrm{TF}_{\text {soil- }}\right.$ plant $>0.5)$ for the first sampling date (Figure 1A). Statistically significant differences were observed between sampling dates with increasing $\mathrm{TF}_{\text {soil-plant }}$ values over time (>2 times for half of the elements, and up to >20 times for Ti), except for Cd and $\mathrm{Sr}$ where no evolution was observed. Zinc showed a singular pattern with higher transfer from soil to plant during the early season.

The root to shoot transfer showed more consistent pattern, both between trace elements and sampling dates (Figure 1B). Cadmium, however, appeared as the lowest transferred element. $\mathrm{TF}_{\text {root-shoot }}$ values were generally higher than TF $\mathrm{F}_{\text {soil-plant }}$ ones, except for $\mathrm{Cd}$, $\mathrm{Cu}$, and $\mathrm{Zn}$. The two other plant species showed similar patterns as described for Trifolium resupinatum for both factors, including the singular $\mathrm{Zn}$ pattern for $\mathrm{TF}_{\text {soil- }}$ plant (Figure S1).

\subsubsection{Trace element relationships}

The PCA performed to identify the relationships between trace elements explained $76 \%$ of data variance with the first two components (Figure $2 \mathrm{~A}$ ). The first component (54\% of data variance) was influenced by $\mathrm{Sr}, \mathrm{Zn}, \mathrm{Cu}$, and $\mathrm{Ba}$ (positive scores) and $\mathrm{Ti}, \mathrm{Pb}, \mathrm{Mn}$, and $\mathrm{Cr}$ (negative scores). This dimension opposed soil solution and, to a lesser extent, soil water extract $(0-30 \mathrm{~cm})$ samples with positive scores and soil samples with negative scores. Also, plant samples have essentially negative scores (up to soil sample ones). The second component (22\% of data variance) grouped $\mathrm{V}$ and $\mathrm{Ba}$ (positive scores) in opposition to $\mathrm{Cd}$ and, to a lesser extent, Co (negative scores). Earthworm samples mostly drove this dimension with negative scores, mainly influenced by $\mathrm{Cd}$ concentrations.

Based on the PCA, we considered contrasting elements ( $\mathrm{Cd}, \mathrm{Cu}$, and $\mathrm{Mn}$ ) to plot relationships between trace elements for all compartments: $\mathrm{Cd} / \mathrm{Mn}$ vs $\mathrm{Cu} / \mathrm{Mn}$ (Figure 2B). Two main end-members emerged: soil (with low $\mathrm{Cd} / \mathrm{Mn}$ and $\mathrm{Cu} / \mathrm{Mn}$ ratios) and soil solution (with higher $\mathrm{Cd} / \mathrm{Mn}$ and $\mathrm{Cu} / \mathrm{Mn}$ ratios, including a higher heterogeneity) samples. Soil water extract samples showed an intermediate signature with $30-50 \mathrm{~cm}$ samples highlighting lower ratio values than 0-30 cm samples. Despite the intermediate position of plant samples, they did not show a linearity between the two end-members: roots showed higher relative $\mathrm{Cd} / \mathrm{Mn}$ ratios while shoots had higher relative $\mathrm{Cu} / \mathrm{Mn}$ ratios. Also, the shoot signature for Triticum spelta was close to the soil-soil solution linear relationship, including samples with higher relative Cd/Mn ratios, unlike Trifolium resupinatum and Vicia faba, and the root signature showed increasing Cd/Mn and Cu/Mn ratios from Triticum spelta to Trifolium resupinatum. Finally, earthworm samples had a higher relative $\mathrm{Cd} / \mathrm{Mn}$ ratio than all other compartments (from 40 to 500 times for soil solution and soil samples, respectively) and the snow sample was located between the two previously mentioned end-members.

\subsection{Rare earth elements}

\subsubsection{Rare earth element concentrations and transfer factors}

Total REE ( $\sum$ REE) showed decreasing concentrations in the following order (Table 1 and Table S1): soil $\left(111 \mathrm{mg} \mathrm{kg}^{-1}\right.$ at $0-30 \mathrm{~cm} \mathrm{depth)} \mathrm{>} \mathrm{root} \mathrm{>}$ shoot > earthworm (1.07 $\left.\mathrm{mg} \mathrm{kg}^{-1}\right)$. Soil water-extract samples represented 0.04 and $0.12 \%$ of soil $\Sigma$ REE concentrations at $0-30$ and $30-50 \mathrm{~cm}$ soil depths, respectively: $\sum$ REE concentrations were about 2.7-times higher at 30-50 cm compared to 0-30 cm. Heavy REE were 42 and $36 \%$

more extractable than LREE at 0-30 and 30-50 cm soil depths, respectively. Moreover, REE extractability was in the same range as Ti, Co, Cr, Mn, and $\mathrm{Pb}$. Soil solutions had $\Sigma \mathrm{REE}$ concentrations of $0.40 \mu \mathrm{g} \mathrm{L}-1$, corresponding to half of the snow sample $\Sigma$ REE concentrations. The soil solution/soil REE concentration ratios showed similar trends as observed for soil water-extract/soil, with increasing ratios of $90 \%$ from LREE to 
HREE. However, it is notable that Ce was relatively less extractable ( 16 and $38 \%$ at $0-30$ and $30-50 \mathrm{~cm}$ depth, respectively) and Eu relatively more extractable (30 and $18 \%$ at $0-30$ and $30-50 \mathrm{~cm}$ depth) compared to their neighboring elements in the periodic table.

The transfer factor of REE from soil to Trifolium resupinatum showed similar pattern as observed for the other trace elements studied with increasing $\mathrm{TF}_{\text {soil-plant }}$ over time, despite no statistically significant difference (Figure 1A). The TF 0.14 according to the element and sampling date) were close to those of $\mathrm{Ti}$, $\mathrm{Cr}$, or $\mathrm{Ba}$. However, distinct behaviors appeared with increasing $\mathrm{TF}_{\text {soil-plant }}$ values of $20 \%$ from average LREE to average HREE. The root to shoot transfer of REE in Trifolium resupinatum showed consistent pattern between sampling dates compared to the other trace elements (Figure 1B). Similar trends were observed for Vicia faba and Triticum spelta (Figure S1).

\subsubsection{REE normalized patterns of soil and soil water-extract samples}

UCC-normalized REE patterns were studied at both 0-30 and 30-50 cm soil depths (Figure $3 \mathrm{~A}$ ). Results showed similar patterns for the three sub-areas, indicating a low spatial heterogeneity. We thus averaged sub-areas in the following results. The comparison between the two soil depths also showed similar patterns. Normalized LREE/HREE ratios were $>1$, with statistically significant higher values ( $<<0.05$ ) in the topsoil (average LREE/HREE ratio of 1.24 and 1.18 at $0-30$ and $30-50 \mathrm{~cm}$ soil depth, respectively). All REE patterns showed a negative Eu anomaly (on average, 0.80 and 0.82 at $0-30$ and $30-50 \mathrm{~cm}$ soil depth, respectively).

To understand the REE transfer from soil to plant, we studied the extractable fraction considering soil water-extract samples normalized by the related soil horizon (0-30 and 30-50 cm soil depth, Figure 3B). The results showed distinct REE behaviors in soil water-extract samples from soil ones: relative MREE enrichment, LREE/HREE ratios < 1, negative Ce anomaly, and positive Eu anomaly (Figure 3B). Although soil waterextract REE patterns were similar between both soil depths, the negative Ce anomaly was more pronounced at $30-50 \mathrm{~cm}$ depth (0.63) compared to $0-30 \mathrm{~cm}$ depth $(0.85)$.

\subsubsection{REE normalized patterns of soil solution and snow samples}

All soil solution samples showed similar soil-normalized REE patterns (Figure 4A), including negative Ce anomaly (on average, 0.61), negative Tb anomaly (0.64), and low LREE/HREE ratios (0.51). These characteristics were not fully observed in soil (Figure $3 \mathrm{~A}$ ) and soil water-extract (Figure 3B) samples. Only the soil solution sample collected on 15 Dec. 2020 was slightly different from the other soil solution samples, with 2.7 -times higher $\Sigma$ REE concentrations and 1.5-times less pronounced negative Ce anomaly.

The only snow sample collected on 14 Jan. 2021 showed distinct REE pattern to soil solution ones: no obvious negative Ce and Tb anomalies and no relative HREE enrichment (Figure 4A). We thus normalized soil solution samples to the snow concentrations to highlight the main differences between these two compartments (Figure 4B). Therefore, snow-normalized REE profiles still showed negative Ce (on average, 0.59) and $\mathrm{Tb}(0.72)$ anomalies and presented a low negative $\mathrm{Yb}$ anomaly $(0.81)$. Beside theses anomalies, the REE profiles were relatively flat with the exception of last HREE (i.e., Tm to Lu) enrichments (LREE/HREE of 0.68).

\subsubsection{REE normalized patterns of plant and earthworm samples}

Three plant species were analyzed distinguishing shoots from roots. Soil-normalized REE patterns showed similar trends between considered both species and organs without noticeable anomaly when comparing to soil compartment (Figure 5A-C). Despite these relatively flat profiles, all REE patterns showed a relative MREE depletion, modifying the LREE/HREE ratio (on average 0.86 for shoots and 0.83 for roots). Rare earth element concentrations, however, highlighted systematic higher values in roots compared to shoots (on average, 6.0 times for Vicia faba, 2.7 times for Trifolium resupinatum, and 3.4 times for Triticum spelta). Also, REE concentrations increased over time in shoots (with the exception of Vicia faba for the first two sampling dates) and roots (with the exception of Triticum spelta). The increasing ratios in the three species between the first sampling date (16 Oct. 2020) and the last one (4 Feb. 2021) were 2.5, 2.7, and 4.1 for shoots of Vicia faba, Trifolium resupinatum, and Triticum spelta, respectively. The respective ratios for roots showed either lower (1.8 for Vicia faba and 2.4 for Trifolium resupinatum) or no evolution over time (for Triticum spelta).

Earthworms from each sub-area were analyzed and indicated different soil-normalized REE patterns than the other compartments considered: LREE/HREE ratios of 0.49 and negative Ce anomaly (0.69) as observed in soil solution samples, but no pronounced negative Tb anomaly (Figure 5D). One composite sample (representing a sub-area) showed singular REE pattern with higher relative HREE concentrations and more pronounced negative Eu anomaly (0.76).

\subsubsection{Rare earth element relationships}

As for trace elements, a PCA was performed on REE concentrations and the first two components accounted for $87 \%$ of data variance (Figure 6A). The first component (70\% of data variance) was influenced by Dy, Er, Ho, Yb, Lu, and Tm (positive scores) and Pr, La, Ce, and Nd (negative scores). As observed on the first component of the trace element PCA (Figure 2A), soil solution and, to a lesser extent, soil water-extract (0-30 
$\mathrm{cm}$ ) samples (positive scores), were opposed to soil samples (negative scores). Also, the REE signatures of plant and soil samples were closer compared to the other trace elements. The second component (17\% of data variance) grouped Sm, Eu, Gd, and, to a lesser extent, $\mathrm{Nd}$ (positive scores).

Based on these results and considering the tracer potential of some REE, we plotted the relationship between Ce/Eu (proxy of both Ce and Eu anomalies) and La/Lu (proxy of LHREE/HREE fractionation) for all samples collected in this study (Figure 6B). Once again, soil solution (with relatively low Ce/Eu and La/Lu ratios) and soil samples (with relatively high Ce/Eu and La/Lu ratios) were the two main end-members. Plant signatures were close to soil ones (despite lower $\mathrm{Ce} / \mathrm{Eu}$ and La/Lu ratios). The heterogeneity of plant samples, however, was neither related to sampling dates nor plant species unlike the other trace elements. Yet, shoots showed higher relative Ce/Eu ratio than roots, resulting in a discrepancy from the linear relationship between the two main end-members. Soil water-extract samples showed an intermediate signature despite lower relative Ce/Eu ratio. Finally, earthworm samples presented a high heterogeneity and the snow sample had a signature between soil and soil water-extract samples.

\section{Discussions}

4.1 Transfer of trace elements from soil to plant

Trace elements concentrations measured in soil and plant samples (Table 1 and Table S1) were in the same order of magnitude as observed in the literature (He et al. 2005, Kabata-Pendias 2010, Antoniadis et al. 2017). Some differences occurred between plant species, with higher root and shoot concentrations in the Poaceae species (Triticum spelta) compared to the two Fabaceae species (Trifolium resupinatum and Vicia $f a b a)$. The transfer of trace elements from soil to plant were investigated using two transfer factors $\left(\mathrm{TF}_{\text {soil-plant }}\right.$ and $\mathrm{TF}_{\text {root-shoot, }}$ Figure 1$)$ that were in the same range as those found in Senesil et al. (1999). Although soil-plant transfer depended on plant species and sampling date, we distinguished weakly transferred elements (including elements without or with low physiological role, such as $\mathrm{Ti}, \mathrm{V}, \mathrm{Pb}, \mathrm{and} \mathrm{Co}$ ) from highly transferred ones (including plant nutrients, such as $\mathrm{Zn}$ and $\mathrm{Cu}$, or $\mathrm{Sr}$ following the metabolic pathway of $\mathrm{Ca}$ ). The physicochemical behavior of the element considered also influences its transfer: for example, Cd had $\mathrm{TF}_{\text {soil-plant }}$ 3-times greater than Pb due to its higher soil mobility and phytoavailability (Angelova et al. 2004). The uptake of essential elements may follow nutritional requirement, as observed for Zn with higher transfer from soil to roots and/or stem at the beginning of the growth (Nan et al. 2002, Wu et al. 2010), while the accumulation of the other elements continuously increased with time. The soil-plant transferability of elements coincided with their soil extractability assessed using the soil water-extract/soil concentration ratio (except for $\mathrm{Mn}$ and V). Interestingly, similar patterns were evidenced for soil solution/soil concentration ratio, indicating commonalities between soil water-extract and soil solution samples: the more extractable an element is, the more it is present in the soil solution. Root to shoot transfer, however, highlighted a low heterogeneity among trace elements (mean TF $_{\text {root-shoot }}$ between 0.15 and 1.06 for Trifolium resupinatum) compared to transfer from soil to plant. An exception was for Cd that presented $\mathrm{TF}_{\text {root-shoot }}<0.13$ : this indicates a low root to shoot transfer despite the Cd root absorption, resulting in a root accumulation of this element (Green et al. 2006).

The concentrations of trace elements considered indicated that the compartments studied behaved differently within the first two dimensions of the PCA (Figure 2A). This observation was confirmed when considering three trace elements with distinct behaviors (Cd, Cu, and Mn): (1) the contrasted geochemical signatures of soil and soil solution samples allowed defining the two end-members of this system in which both plant and soil water-extract samples were located, (2) some compartments, especially soil solutions and soil water-extracts, presented a high heterogeneity according to the sampling date, sub-area, or soil depth, and (3) the different signatures of roots and shoots highlight distinct soilroot-shoot transfer processes, resulting in a discrepancy from the soil-soil solution linear relationship (Figure 2B). The latter trends may be related to the transfer factors: high $\mathrm{Cu}$ uptake by plant and transfer to shoot vs $\mathrm{Cd}$ accumulation in roots as previously mentioned (Figure 1 ).

\subsection{Transfer of rare earth elements from soil to plant}

Soil $\sum$ REE concentrations measured in this study $\left(111 \mathrm{mg} \mathrm{kg}^{-1}\right)$ were in the same range as European soil data (126 mg kg ${ }^{-1}$, Fedele et al. 2008 , Mihajlovic and Rinklebe 2018). Similar soil $\sum$ REE concentrations and REE patterns between sub-areas and soil depths indicate that the soil is relatively homogeneous across space (Figure 3A). Moreover, soil REE patterns were similar to plant ones, both for shoots and roots (Figure $5 \mathrm{~A}-\mathrm{C}$ ). This highlights that the plant REE composition is largely influenced by the soil chemical composition. However, slight differences of chemical behaviors between LREE and HREE occurred throughout the soil-plant pathway: our results indicate higher HREE extractability (+42\% for the topsoil), occurrence in soil solution (+90\% after soil-normalization), and soil-plant transfer (+20\% from the topsoil) compared to LREE. Despite higher LREE solubility reported in the literature (Tyler 2004, Stille et al. 2006), we suggest a higher HREE mobility (from soil to soil solution, Cidu et al. 2013), and thus plant bioavailability, instead of HREE leaching due to complexation during weathering, as reported by Laveuf and Cornu (2009). We hypothesize that: (1) REE fractionation is limited in the plant species studied (cover crop species), and/or (2) the relative nonenrichment of HREE in the soils studied limits this fractionation.

The REE transfer from soil to plant (average $\mathrm{TF}_{\text {soil-plant }}$ of 0.07) was comparable as data reported by Tyler (2004). Root REE concentrations higher than shoot ones are frequently found in various crop species (Li et al. 1998, Lihong et al. 1999, Xu et al. 2002), resulting from higher soil- 
root transfer than root-shoot transfer. This is due to the Casparian strip in roots that limits the REE transfer (Brioschi et al. 2013). Moreover, no differences were evidenced between plant species (two Fabaceae and one Poaceae species), unlike previous findings including trees, dwarf shrubs, and fern (Wyttenbach et al. 1998a). We assume that the plant species selected in our study were more comparable in terms of plant physiology or rooting depth, which limited plant uptake differences. Furthermore, all parts of plants showed an obvious concentration increase over time (up to 4 times, Figure $5 \mathrm{~A}-\mathrm{C}$ ), which reveals the element accumulation with time, as observed for the other trace elements (Figure 1). However, differences occurred between REE with increasing Ce/Eu ratio from roots to shoots (Figure 6B). Yet, since Ce extractability is relatively low and Eu extractability relatively high, we assume that plant physiology modifies physicochemical conditions in plant organs or constrains substitution with cations (Brioschi et al. 2013), generating a higher Eu accumulation and/or a lower Ce accumulation in shoots compared to roots.

Soil water-extract samples showed low REE extractability compared to the few data available in the literature (Wyttenbach et al. 1998b, Wiche et al. 2017), probably due to different extraction protocols used (water vs ammonium acetate in the literature). However, REE extractability increased with soil depth, as observed by Wyttenbach et al. (1998b). The difference of negative Ce anomaly between both soil water-extract samples (Figure 3B) may be explained by: (1) higher mineral content in the deeper soil horizon, such as Fe and Mn oxyhydroxides, promoting the Ce adsorption (Brioschi et al. 2013), or (2) higher soil organic matter content in topsoil (Leleyter et al. 1999, Cidu et al. 2013). Indeed, Ce has a less organic matter affinity than the other LREE, explaining the lowest relative Ce content in topsoil (Davranche et al. 2005). This is supported by a strongest negative Ce anomaly in earthworms feeding on soil organic matter (Figure 5D), as well as the relative HREE enrichment probably resulting from higher affinity with organic matter (Cidu et al. 2013). Negative Ce anomaly also appeared in soil solution samples due to either Ce adsorption on soil minerals particularly significant as $\mathrm{Ce}^{4+}$ in oxidized surface waters (Leybourne et al. 2000) or influence of dissolved organic matter (Figure 4). The hypothesize of adsorption on colloids or on organic matter is supported by the relative HREE enrichment in this matrix (Laveuf and Cornu 2009, Cidu et al. 2013). The strong negative Tb anomaly observed in all soil solution samples (on average 0.64, soilnormalization, Figure 4A), and only slightly present in soil water-extract samples, could be partially originated from atmospheric deposition, although no evidence was provided by the only snow sample collected during this study (on average 0.72, snow-normalization, Figure 4B). Yet, relative MREE enrichment (Figure 4A) was already reported in both wet and dry atmospheric deposition (Sholkovitz et al. 1993).

All geochemical behaviors of REE between compartments in the soil-plant continuum studied and gaps identified were summarized in the Figure 7, including comparison between UCC-normalized patterns.

\subsection{Rare earth elements for tracing the soil-plant transfer of trace elements}

The results obtained for trace elements and REE indicate similarities in geochemical behaviors among the compartments studied. Indeed, in either case plant samples were between soil and soil solution signatures, both being considered as the two end-members of the soil-plant system (Figure 2 and Figure 6). This highlights that soil solutions and, to a lesser extent soil-water extracts, do not represent the geochemical signature of plant bioavailable chemical fraction. Moreover, these two compartments were relatively heterogeneous in time (for soil solutions) and space (for soil solutions and soil water-extracts). For instance, according to the protocol employed to collect soil solution ( $\mathrm{pF} 3.46 \mathrm{using}$ a $60 \mathrm{~mL}$ syringe with rhizon), samples likely include both capillary and gravitational water, the latter might be influenced by atmospheric deposition that would modify the chemical composition. Thus, they must be considered with caution to assess the soil-plant transfer of elements.

Both soil solution and soil water-extract samples, however, followed similar trends. For example, linear relationship was highlighted between soil extractability (i.e., soil water-extract/soil concentration ratio) and soil solution/soil concentration ratio (Figure 8A), including a significant range in the REE distribution, despite Eu and Tb discrepancies. Considering now soil extractability as a potential proxy of element bioavailability and effective soil-plant transfer ( $\mathrm{TF}_{\text {soil-plant }}$ ), we notice a more heterogeneous element distribution compared to the previous plot (Figure 8B). Even if the most extractable elements were generally the most transferred elements from soil to plant, some exceptions occur: Ba, Cd, and $\mathrm{V}$ presented a relatively lower transfer compared to their extractability, while Ti and Sr showed the opposite trend. Unlike in the soil extractability vs

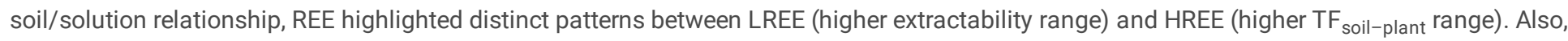

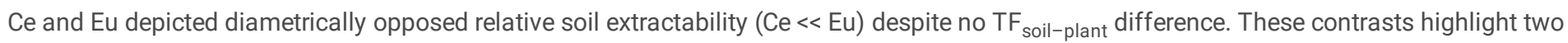
distinct indications: (1) the Ce/Eu ratio (or Ce and Eu anomalies) is mainly influenced by the soil-solution element mobility, and (2) the LREE/HREE ratio is influenced by the bioavailability of elements. Yet, in both cases, interaction with mineral or organic colloids present in the solution may modify these patterns. Further research should thus compare contrasted soils, including in terms of mineral and organic content, for characterizing the effect of colloids in soil solutions.

\section{Conclusions}

This paper aimed at evaluating to what extent the REE monitoring allows identifying preferential pathway of trace elements in the soil-plant continuum comparing geochemical signatures in the different compartments (soil, water, plant). For this purpose, we conjointly analyzed trace element and REE concentrations in soils, roots, shoots, soil water-extracts, and soil solutions in an intercropping cover crop. Results showed

Page $8 / 16$ 
increasing soil-plant transfer of trace elements (from $\mathrm{Ti}, \mathrm{V}, \mathrm{Pb}$, and $\mathrm{Co}$ to $\mathrm{Zn}, \mathrm{Cu}$, and $\mathrm{Sr}$ ) relative to their biological roles or substitution potential. The main findings are that REE patterns were similar in soil, root, and shoot compartments showing the large influence of soil REE composition on plant one and the low plant species effect. However, HREE were slightly more transferred to plants than LREE, resulting from higher soil extractability and occurrence in soil solutions. Also, Ce and Eu presented different extractability than their neighboring elements and an increasing $\mathrm{Ce} /$ Eu ratio was observed from root to shoot resulting from distinct transfer processes. Soil solution and soil water-extract samples presented distinct geochemical signatures compared to soil and plant for both trace elements and REE. This demonstrates that they are not representative of the fraction that can be uptaken by plants (soil solution might also include gravitational water fraction). However, LREE/HREE and $\mathrm{Ce} / \mathrm{Eu}$ ratios in soil solution and soil water-extract samples can be used as indicators of environmental conditions (such as colloid adsorption or organic matter complexation).

\section{Declarations}

Acknowledgements

Thanks to Hugues Falys for the sampling site access to the centre de Marbaix (UCLouvain) and providing relevant advice. We also thank Laurence Monin and Élodie Devos for the ICP-MS analytical support and Claudine Givron for the carbon analysis.

\section{Funding}

This work was financially supported by the Fonds special de recherche (FSR) from UCLouvain.

\section{Competing interests}

The authors declare that they have no known competing financial interests or personal relationships that could have appeared to influence the work reported in this paper.

\section{Author Contributions}

Bryan Arbalestrie: Validation, Formal analysis, Investigation, Writing - original draft. Julie Falys: Methodology, Validation, Formal analysis, Investigation, Writing - review \& editing, Visualization. Nathan Bemelmans: Writing - review \& editing. Adil Thami: Writing - review \& editing. Yannick Agnan: Conceptualization, Formal analysis, Writing - original draft, Writing - review \& editing, Visualization, Supervision, Project administration, Funding acquisition

\section{Data Availability}

The datasets generated during the current study are available in the electronic supplementary material (Table S1).

\section{References}

1. Adriano DC (2001) Trace elements in terrestrial environments: biogeochemistry, bioavailability, and risks of metals, 2nd ed. Springer, New York

2. Agnan Y, Séjalon-Delmas N, Probst A (2014) Origin and distribution of rare earth elements in various lichen and moss species over the last century in France. Sci Total Environ 487:1-12. https://doi.org/10.1016/j.scitotenv.2014.03.132

3. Angelova V, Ivanov K, Ivanova R (2004) Effect of chemical forms of lead, cadmium, and zinc in polluted soils on their uptake by tobacco. J Plant Nutr 27:757-773. https://doi.org/10.1081/PLN-120030609

4. Antoniadis V, Levizou E, Shaheen SM, et al (2017) Trace elements in the soil-plant interface: Phytoavailability, translocation, and phytoremediation-A review. Earth-Sci Rev 171:621-645. https://doi.org/10.1016/j.earscirev.2017.06.005

5. Aubert D, Stille P, Probst A (2001) REE fractionation during granite weathering and removal by waters and suspended loads: Sr and Nd isotopic evidence. Geochim Cosmochim Acta 65:387-406. https://doi.org/Article

6. Brioschi L, Steinmann M, Lucot E, et al (2013) Transfer of rare earth elements (REE) from natural soil to plant systems: implications for the environmental availability of anthropogenic REE. Plant Soil 366:143-163. https://doi.org/10.1007/s11104-012-1407-0

7. Cantrell KJ, Byrne RH (1987) Rare earth element complexation by carbonate and oxalate ions. Geochim Cosmochim Acta 51:597-605. https://doi.org/10.1016/0016-7037(87)90072-X

8. Cao X, Chen Y, Wang X, Deng X (2001) Effects of redox potential and pH value on the release of rare earth elements from soil. Chemosphere 44:655-661. https://doi.org/10.1016/S0045-6535(00)00492-6

9. Cidu R, Vittori Antisari L, Biddau R, et al (2013) Dynamics of rare earth elements in water-soil systems: The case study of the Pineta San Vitale (Ravenna, Italy). Geoderma 193-194:52-67. https://doi.org/10.1016/j.geoderma.2012.10.009

Page 9/16 
10. Davranche M, Gruau G, Dia A, et al (2015) Biogeochemical factors affecting rare earth element distribution in shallow wetland groundwater. Aquat Geochem 21:197-215. https://doi.org/10.1007/s10498-014-9247-6

11. Davranche M, Grybos M, Gruau G, et al (2011) Rare earth element patterns: a tool for identifying trace metal sources during wetland soil reduction. Chem Geol 284:127-137. https://doi.org/10.1016/j.chemgeo.2011.02.014

12. Davranche M, Pourret $\mathrm{O}$, Gruau G, et al (2005) Adsorption of REE(III)-humate complexes onto $\mathrm{MnO}_{2}$ : Experimental evidence for cerium anomaly and lanthanide tetrad effect suppression. Geochim Cosmochim Acta 69:4825-4835. https://doi.org/10.1016/j.gca.2005.06.005

13. Dinno A (2017) dunn.test: Dunn's Test of Multiple Comparisons Using Rank Sums. Version 1.3.5. R package version 1.3.5. URL https://CRAN.R-project.org/package=dunn.test

14. Fedele L, Plant JA, Vivo BD, Lima A (2008) The rare earth element distribution over Europe: geogenic and anthropogenic sources. Geochem Explor Environ Anal 8:3-18. https://doi.org/10.1144/1467-7873/07-150

15. Garrett RG (2013) The 'rgr' package for the R Open Source statistical computing and graphics environment - a tool to support geochemical data interpretation. Geochem Explor Environ Anal 13:355-378. https://doi.org/10.1144/geochem2011-106

16. Green ID, Jeffries C, Diaz A, Tibbett M (2006) Contrasting behaviour of cadmium and zinc in a soil-plant-arthropod system. Chemosphere 64:1115-1121. https://doi.org/10.1016/j.chemosphere.2005.11.074

17. He ZL, Yang XE, Stoffella PJ (2005) Trace elements in agroecosystems and impacts on the environment. J Trace Elem Med Biol 19:125140. https://doi.org/10.1016/j.jtemb.2005.02.010

18. Henderson P (1984) Rare earth element geochemistry. Elsevier, Amsterdam

19. Hu Z, Haneklaus S, Sparovek G, Schnug E (2006) Rare earth elements in soils. Commun Soil Sci Plant Anal 37:1381-1420. https://doi.org/10.1080/00103620600628680

20. Iwashita M, Saito A, Arai M, et al (2011) Determination of rare earth elements in rainwater collected in suburban Tokyo. Geochem J 45:187197

21. Kabata-Pendias A (2010) Trace elements in soils and plants, 4th edn. CRC Press

22. Kabata-Pendias A (2004) Soil-plant transfer of trace elements-an environmental issue. Geoderma 122:143-149. https://doi.org/10.1016/j.geoderma.2004.01.004

23. Krzciuk K, Gałuszka A (2020) Presence and possible origin of positive Eu anomaly in shoot samples of Juncus effusus L. J Trace Elem Med Biol 58:126432. https://doi.org/10.1016/j.jtemb.2019.126432

24. Laveuf C, Cornu S (2009) A review on the potentiality of rare earth elements to trace pedogenetic processes. Geoderma 154:1-12. https://doi.org/10.1016/j.geoderma.2009.10.002

25. Laveuf C, Cornu S, Juillot F (2008) Rare earth elements as tracers of pedogenetic processes. Comptes Rendus Geosci 340:523-532. https://doi.org/10.1016/j.crte.2008.07.001

26. Lê S, Josse J, Husson F (2008) FactoMineR: An R package for multivariate analysis. J Stat Softw 25:. https://doi.org/10.18637/jss.v025.i01

27. Leleyter L, Probst J-L, Depetris P, et al (1999) REE in river sediments: partitioning into residual and labile fractions. Comptes Rendus Acad Sci 329:45-52. https://doi.org/10.1016/S1251-8050(99)80226-2

28. Leybourne MI, Goodfellow WD, Boyle DR, Hall GM (2000) Rapid development of negative Ce anomalies in surface waters and contrasting REE patterns in groundwaters associated with $\mathrm{Zn}-\mathrm{Pb}$ massive sulphide deposits. Appl Geochem 15:695-723. https://doi.org/10.1016/S0883-2927(99)00096-7

29. Li F, Shan X, Zhang T, Zhang S (1998) Evaluation of plant availability of rare earth elements in soils by chemical fractionation and multiple regression analysis. Environ Pollut 102:269-277. https://doi.org/10.1016/S0269-7491(98)00063-3

30. Liang T, Ding S, Song W, et al (2008) A review of fractionations of rare earth elements in plants. J Rare Earths 26:7-15. https://doi.org/10.1016/S1002-0721(08)60027-7

31. Liang T, Zhang S, Wang L, et al (2005) Environmental biogeochemical behaviors of rare earth elements in soil-plant systems. Environ Geochem Health 27:301-311. https://doi.org/10.1007/s10653-004-5734-9

32. Lihong Y, Xiaorong W, Hao S, Haishi Z (1999) The effect of EDTA on rare earth elements bioavailability in soil ecosystem. Chemosphere 38:2825-2833. https://doi.org/10.1016/S0045-6535(98)00496-2

33. Marchiol L, Assolari S, Sacco P, Zerbi G (2004) Phytoextraction of heavy metals by canola (Brassica napus) and radish (Raphanus sativus) grown on multicontaminated soil. Environ Pollut 132:21-27. https://doi.org/10.1016/j.envpol.2004.04.001

34. Martinez RE, Pourret O, Faucon M-P, Dian C (2018) Effect of rare earth elements on rice plant growth. Chem Geol 489:28-37. https://doi.org/10.1016/j.chemgeo.2018.05.012

35. Miao L, Xu R, Ma Y, et al (2008) Geochemistry and biogeochemistry of rare earth elements in a surface environment (soil and plant) in South China. Environ Geol 56:225-235. https://doi.org/10.1007/s00254-007-1157-0

Page $10 / 16$ 
36. Mihajlovic J, Rinklebe J (2018) Rare earth elements in German soils - A review. Chemosphere 205:514-523. https://doi.org/10.1016/j.chemosphere.2018.04.059

37. Nan Z, Zhao C, Li J, et al (2002) Relations between soil properties and selected heavy metal concentrations in spring wheat (Triticum aestivum L.) grown in contaminated soils. Water Air Soil Pollut 133:205-213. https://doi.org/10.1023/A:1012962604095

38. Pourret O, Davranche M, Gruau G, Dia A (2008) New insights into cerium anomalies in organic-rich alkaline waters. Chem Geol 251:120-127. https://doi.org/10.1016/j.chemgeo.2008.03.002

39. Pourret O, van der Ent A, Hursthouse A, et al (2021) The 'europium anomaly' in plants: facts and fiction. Plant Soil. https://doi.org/10.1007/s11104-021-05210-6

40. R Core Team (2021) R: A language and environment for statistical computing. Version 4.0.4. R Foundation for Statistical Computing, Vienna, Austria. URL https://www.R-project.org/

41. Ramos SJ, Dinali GS, Oliveira C, et al (2016) Rare earth elements in the soil environment. Curr Pollut Rep 2:28-50. https://doi.org/10.1007/s40726-016-0026-4

42. Rauch JN, Pacyna JM (2009) Earth's global Ag, Al, Cr, Cu, Fe, Ni, Pb, and Zn cycles. Glob Biogeochem Cycles 23:16 pp. https://doi.org/200910.1029/2008GB003376

43. Rudnick RL, Gao S (2014) Composition of the continental crust. In: Holland HD, Turekian KK (eds) Treatise on geochemistry, 2nd edn. Elsevier, Oxford, pp 1-51

44. Senesil GS, Baldassarre G, Senesi N, Radina B (1999) Trace element inputs into soils by anthropogenic activities and implications for human health. Chemosphere 39:343-377. https://doi.org/10.1016/S0045-6535(99)00115-0

45. Sholkovitz ER, Church TM, Arimoto R (1993) Rare earth element composition of precipitation, precipitation particles, and aerosols. J Geophys Res Atmospheres 98:20587-20599. https://doi.org/10.1029/93JD01926

46. Stille P, Steinmann M, Pierret M-C, et al (2006) The impact of vegetation on REE fractionation in stream waters of a small forested catchment (the Strengbach case). Geochim Cosmochim Acta 70:3217-3230. https://doi.org/10.1016/j.gca.2006.04.028

47. Tyler G (2004) Rare earth elements in soil and plant systems - a review. Plant Soil 267:191-206. https://doi.org/10.1007/s11104-005-48882

48. Wiche O, Zertani V, Hentschel W, et al (2017) Germanium and rare earth elements in topsoil and soil-grown plants on different land use types in the mining area of Freiberg (Germany). J Geochem Explor 175:120-129. https://doi.org/10.1016/j.gexplo.2017.01.008

49. Wickham H (2016) ggplot2: elegant graphics for data analysis, 2nd edn. Springer, New York

50. Wu C, Lu L, Yang X, et al (2010) Uptake, translocation, and remobilization of zinc absorbed at different growth stages by rice genotypes of different Zn densities. J Agric Food Chem 58:6767-6773. https://doi.org/10.1021/jf100017e

51. Wyttenbach A, Furrer V, Schleppi P, Tobler L (1998a) Rare earth elements in soil and in soil-grown plants. Plant Soil 199:267-273. https://doi.org/10.1023/A:1004331826160

52. Wyttenbach A, Tobler L, Schleppi P, Furrer V (1998b) Variation of the rare earth element concentrations in the soil, soil extract and in individual plants from the same site. J Radioanal Nucl Chem 231:101-106

53. Xu X, Zhu W, Wang Z, Witkamp G-J (2002) Distributions of rare earths and heavy metals in field-grown maize after application of rare earthcontaining fertilizer. Sci Total Environ 293:97-105. https://doi.org/10.1016/S0048-9697(01)01150-0

\section{Tables}

Table 1. Summary table (means and standard deviations) of trace element and sum of rare earth element ( $\left.\sum \mathrm{REE}\right)$ concentrations for each compartment sampled at the centre de Marbaix. 


\begin{tabular}{|c|c|c|c|c|c|c|c|c|c|c|c|c|c|c|}
\hline \multicolumn{2}{|l|}{ Matrix } & $\mathrm{n}$ & $\mathrm{Ba}$ & Cd & Co & $\mathrm{Cr}$ & $\mathrm{Cu}$ & Mn & $\mathrm{Pb}$ & $\mathrm{Sr}$ & $\mathrm{Ti}$ & V & $\mathrm{Zn}$ & $\Sigma$ REE \\
\hline & & & \multicolumn{12}{|c|}{$m g \mathrm{~kg}^{-1}$} \\
\hline \multirow[t]{2}{*}{ Soil } & $\begin{array}{l}0-30 \\
\mathrm{~cm}\end{array}$ & 3 & $\begin{array}{l}230 \\
(10.3)\end{array}$ & $\begin{array}{l}0.33 \\
(0.03)\end{array}$ & $\begin{array}{l}9.01 \\
(0.64)\end{array}$ & $\begin{array}{l}58.0 \\
(3.65)\end{array}$ & $\begin{array}{l}13.7 \\
(1.33)\end{array}$ & $\begin{array}{l}315 \\
(21.3)\end{array}$ & $\begin{array}{l}21.4 \\
(1.20)\end{array}$ & $\begin{array}{l}37.7 \\
(2.15)\end{array}$ & $\begin{array}{l}2030 \\
(399)\end{array}$ & $\begin{array}{l}64.3 \\
(5.28)\end{array}$ & $\begin{array}{l}45.8 \\
(0.94)\end{array}$ & $\begin{array}{l}111 \\
(14.2)\end{array}$ \\
\hline & $\begin{array}{l}30- \\
50 \\
\mathrm{~cm}\end{array}$ & 3 & $\begin{array}{l}226 \\
(9.29)\end{array}$ & $\begin{array}{l}0.18 \\
(0.03)\end{array}$ & $\begin{array}{l}9.31 \\
(1.57)\end{array}$ & $\begin{array}{l}62.8 \\
(2.83)\end{array}$ & $\begin{array}{l}12.2 \\
(1.49)\end{array}$ & $\begin{array}{l}263 \\
(87.5)\end{array}$ & $\begin{array}{l}15.1 \\
(1.18)\end{array}$ & $\begin{array}{l}32.0 \\
(6.07)\end{array}$ & $\begin{array}{l}2606 \\
(419)\end{array}$ & $\begin{array}{l}64.5 \\
(7.41)\end{array}$ & $\begin{array}{l}36.0 \\
(2.71)\end{array}$ & $\begin{array}{l}106 \\
(10.4)\end{array}$ \\
\hline \multirow[t]{2}{*}{ Plant } & shoot & 27 & $\begin{array}{l}20.4 \\
(12.0)\end{array}$ & $\begin{array}{l}0.08 \\
(0.09)\end{array}$ & $\begin{array}{l}0.51 \\
(0.39)\end{array}$ & $\begin{array}{l}6.70 \\
(4.80)\end{array}$ & $\begin{array}{l}8.25 \\
(2.38)\end{array}$ & $\begin{array}{l}44.5 \\
(21.2)\end{array}$ & $\begin{array}{l}1.36 \\
(1.16)\end{array}$ & $\begin{array}{l}18.0 \\
(7.47)\end{array}$ & $\begin{array}{l}114 \\
(108)\end{array}$ & $\begin{array}{l}3.74 \\
(4.02)\end{array}$ & $\begin{array}{l}40.1 \\
(12.8)\end{array}$ & $\begin{array}{l}7.93 \\
(6.84)\end{array}$ \\
\hline & root & 27 & $\begin{array}{c}61.2 \\
(25.2)\end{array}$ & $\begin{array}{l}0.41 \\
(0.18)\end{array}$ & $\begin{array}{l}1.83 \\
(0.75)\end{array}$ & $\begin{array}{l}26.1 \\
(27.5)\end{array}$ & $\begin{array}{l}15.8 \\
(5.64)\end{array}$ & $\begin{array}{l}101 \\
(39.5)\end{array}$ & $\begin{array}{l}4.99 \\
(3.40)\end{array}$ & $\begin{array}{l}27.4 \\
(7.26)\end{array}$ & $\begin{array}{l}301 \\
(227)\end{array}$ & $\begin{array}{l}15.6 \\
(6.26)\end{array}$ & $\begin{array}{l}56.5 \\
(36.6)\end{array}$ & $\begin{array}{l}28.9 \\
(12.4)\end{array}$ \\
\hline \multicolumn{2}{|c|}{ Earthworm } & 3 & $\begin{array}{l}2.61 \\
(0.56)\end{array}$ & $\begin{array}{l}6.47 \\
(0.78)\end{array}$ & $\begin{array}{l}3.50 \\
(0.79)\end{array}$ & $\begin{array}{l}0.68 \\
(0.08)\end{array}$ & $\begin{array}{l}7.16 \\
(0.17)\end{array}$ & $\begin{array}{l}19.7 \\
(11.0)\end{array}$ & $\begin{array}{l}0.47 \\
(0.20)\end{array}$ & $\begin{array}{l}8.46 \\
\text { (3.06) }\end{array}$ & $\begin{array}{l}13.7 \\
(1.04)\end{array}$ & $\begin{array}{l}0.71 \\
(0.01)\end{array}$ & $\begin{array}{l}335 \\
(9.15)\end{array}$ & $\begin{array}{l}1.07 \\
(0.19)\end{array}$ \\
\hline & & & \multicolumn{12}{|l|}{$\mu g \mathrm{~kg}^{-1}$} \\
\hline \multirow{2}{*}{$\begin{array}{l}\text { Soil } \\
\text { water- } \\
\text { extract }\end{array}$} & $\begin{array}{l}0-30 \\
\mathrm{~cm}\end{array}$ & 3 & $\begin{array}{l}136 \\
(109)\end{array}$ & $\begin{array}{l}0.08 \\
(0.03)\end{array}$ & $\begin{array}{l}0.28 \\
(0.17)\end{array}$ & $\begin{array}{l}1.82 \\
(1.04)\end{array}$ & $\begin{array}{l}8.31 \\
(1.11)\end{array}$ & $\begin{array}{l}13.0 \\
(10.3)\end{array}$ & $\begin{array}{l}1.21 \\
(1.52)\end{array}$ & $\begin{array}{l}11.8 \\
(1.34)\end{array}$ & $\begin{array}{l}20.8 \\
(12.0)\end{array}$ & $\begin{array}{l}9.44 \\
(2.08)\end{array}$ & $\begin{array}{l}87.2 \\
(79.7)\end{array}$ & $\begin{array}{l}4.95 \\
(3.86)\end{array}$ \\
\hline & $\begin{array}{l}30- \\
50 \\
\mathrm{~cm}\end{array}$ & 3 & $\begin{array}{l}62.3 \\
(67.2)\end{array}$ & $\begin{array}{l}0.04 \\
(0.02)\end{array}$ & $\begin{array}{l}0.46 \\
(0.21)\end{array}$ & $\begin{array}{l}3.49 \\
(1.34)\end{array}$ & $\begin{array}{l}4.11 \\
(1.12)\end{array}$ & $\begin{array}{l}16.8 \\
(14.2)\end{array}$ & $\begin{array}{l}1.21 \\
(0.97)\end{array}$ & $\begin{array}{l}9.62 \\
(1.97)\end{array}$ & $\begin{array}{l}59.8 \\
(18.2)\end{array}$ & $\begin{array}{l}5.49 \\
(3.35)\end{array}$ & $\begin{array}{l}26.9 \\
(32.7)\end{array}$ & $\begin{array}{l}13.2 \\
(10.3)\end{array}$ \\
\hline
\end{tabular}

\begin{tabular}{lcccccccccccccccc}
\hline \multicolumn{10}{c}{$\mu g L^{-1}$} \\
Soil solution & 15 & 22.6 & 0.02 & 0.16 & 0.47 & 5.00 & 2.46 & 0.08 & 79.4 & 0.82 & 2.90 & 160 \\
& & $(7.05)$ & $(0.00)$ & $(0.04)$ & $(0.12)$ & $(2.04)$ & $(2.13)$ & $(0.13)$ & $(9.48)$ & $(0.85)$ & $(0.55)$ & $(85.5)$ & $(0.32)$ \\
\hline Snow & 1 & 1.69 & 0.03 & 0.10 & 0.66 & 2.75 & 9.73 & 1.24 & 1.48 & 1.84 & 0.43 & 33.7 & 0.86
\end{tabular}

\section{Figures}
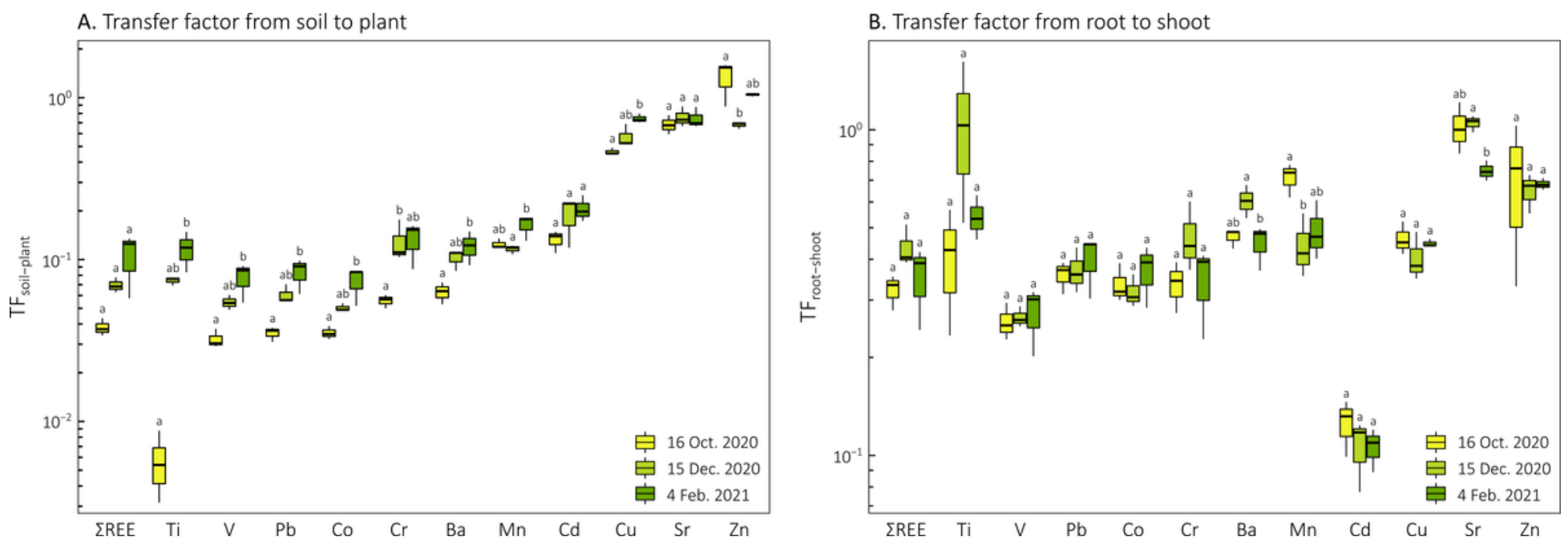

Figure 1

Transfer factors from soil to plant (TFsoil-plant; A) and from root to shoot (TFroot-shoot; B) of trace elements and sum of rare earth elements ( $(\mathrm{REE})$ in Persian clover (Trifolium resupinatum) collected at three sampling dates at the centre de Marbaix. Letters indicate statistically significant differences between sampling dates. 

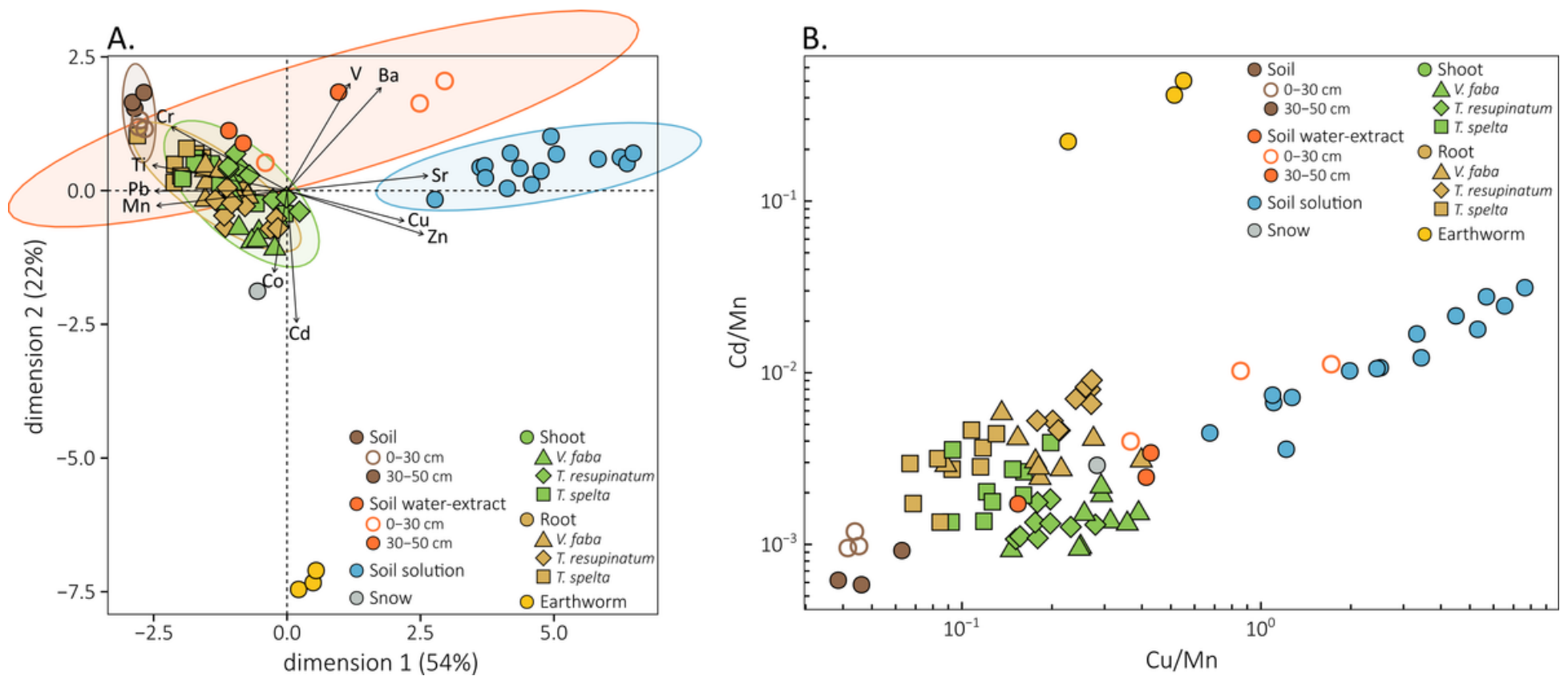

Figure 2

Principal component analysis of log-ratio transformed trace element concentrations in samples collected at the centre de Marbaix (A) and trace element relationship (Cd/Mn vs $\mathrm{Cu} / \mathrm{Mn} ; \mathrm{B})$.
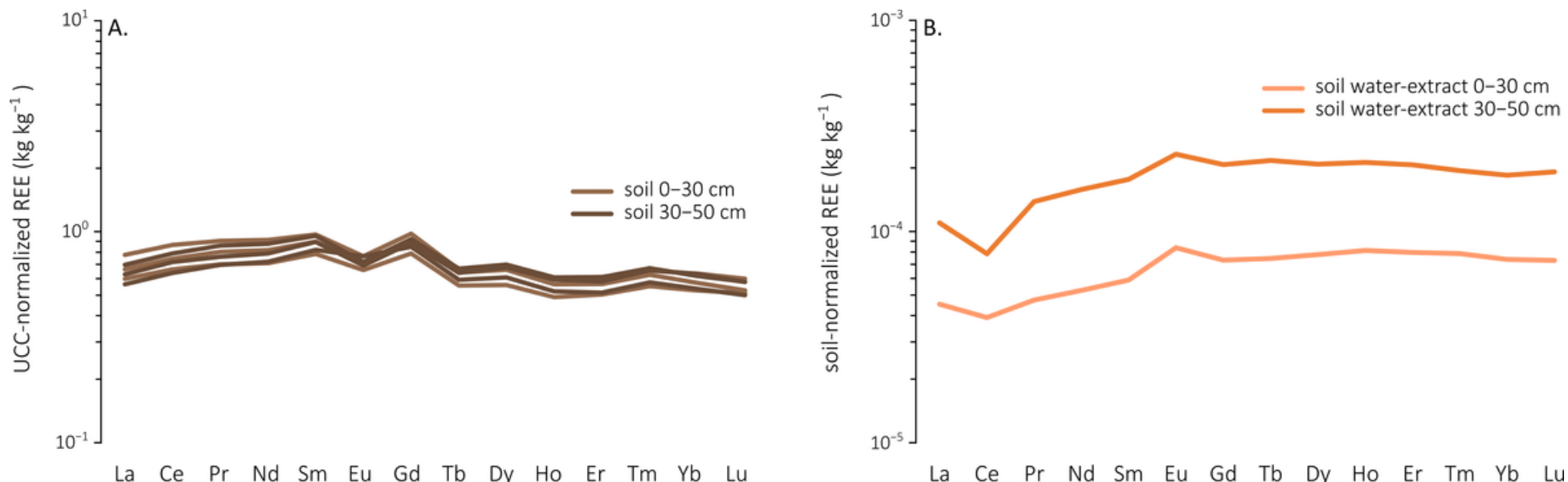

Figure 3

UCC-normalized profiles of rare earth elements (REE) from soil samples collected at the centre de Marbaix (A) and soil-normalized profiles of REE from soil water-extract samples (B). Three composite replicates, corresponding to different sub-areas, were performed for each depth (0-30 $\mathrm{cm}$ and $30-50 \mathrm{~cm}$ ). 

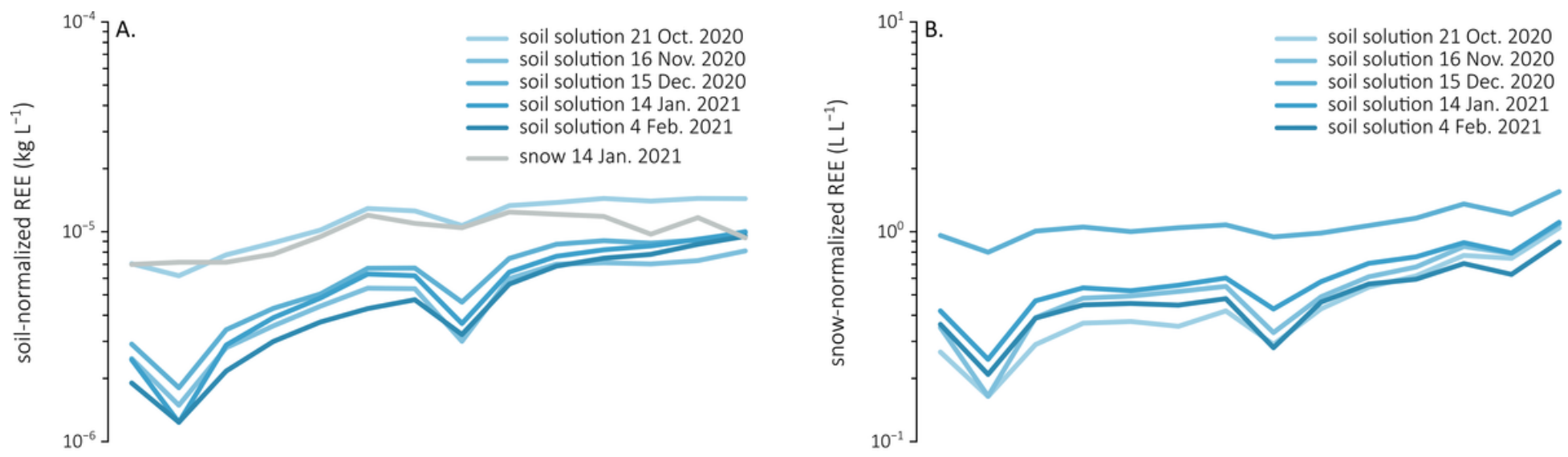

La Ce Pr Nd Sm Eu Gd Tb Dy Ho Er Tm Yb Lu

La Ce Pr Nd Sm Eu Gd Tb Dy Ho Er Tm Yb Lu

\section{Figure 4}

Soil-normalized (A) and snow-normalized (B) profiles of rare earth elements (REE) from soil solution and snow samples collected at the centre de Marbaix.
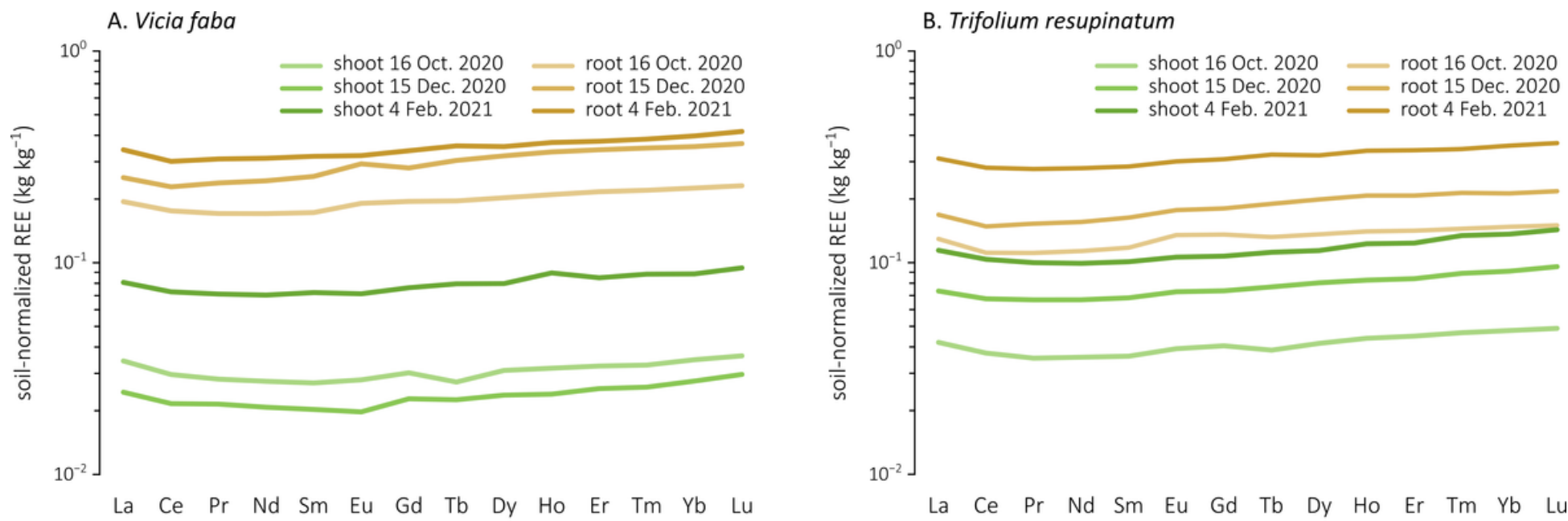

\section{Triticum spelta}

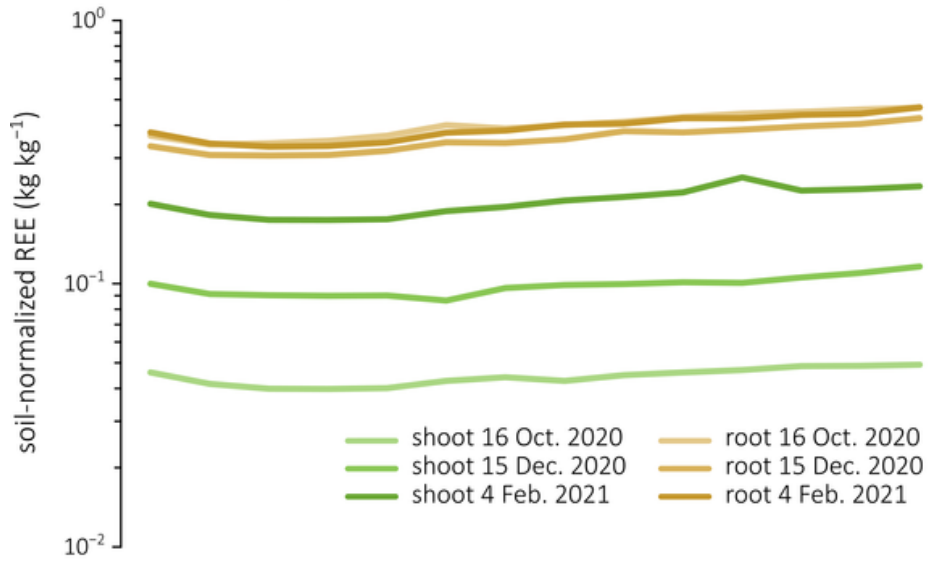

La Ce Pr Nd Sm Eu Gd Tb Dy Ho Er Tm Yb Lu

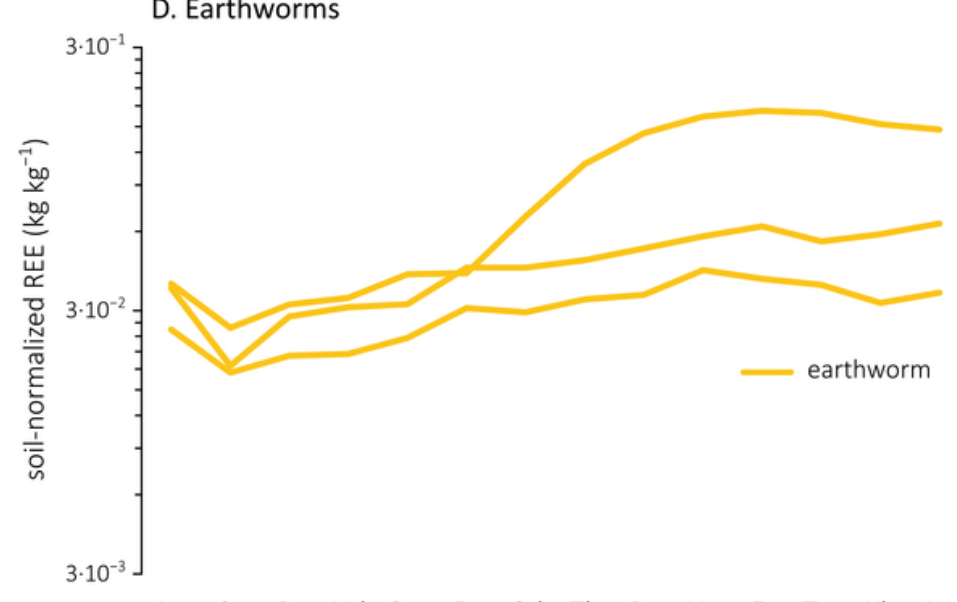

Figure 5

Soil-normalized profiles of rare earth elements (REE) from plant (shoot and root) and earthworm samples collected at the centre de Marbaix: bean (Vicia faba; A), Persian clover (Trifolium resupinatum; B), spelt (Triticum spelta; C), and earthworms (D). 


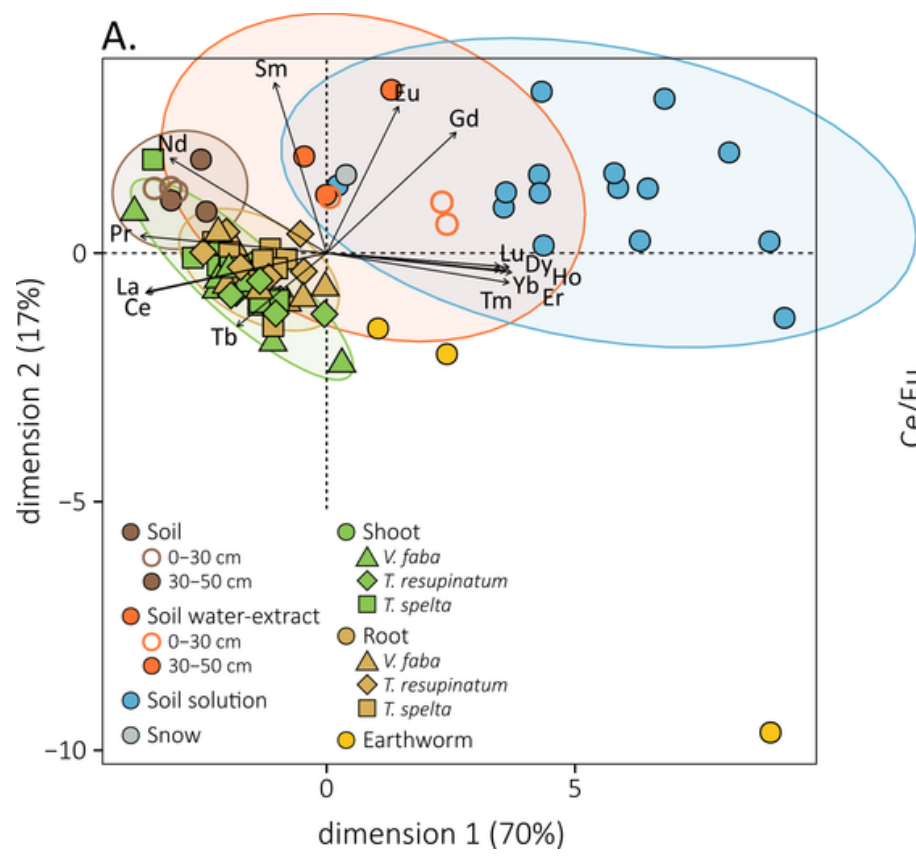

\section{B.}

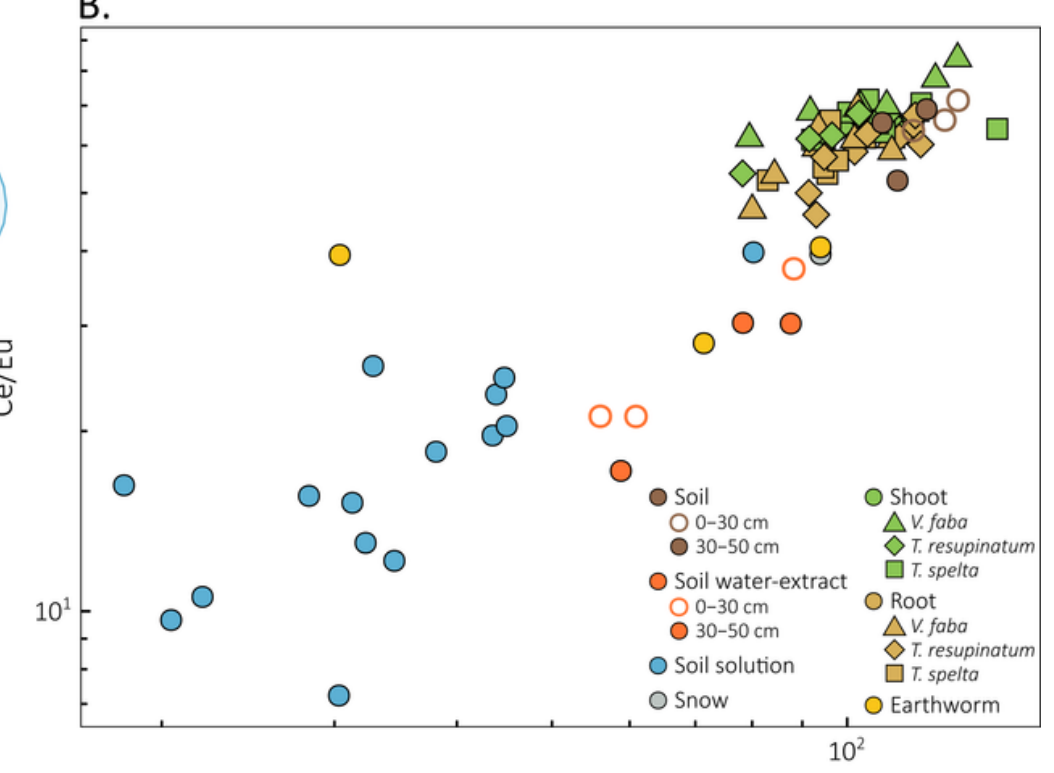

$\mathrm{La} / \mathrm{Lu}$

Figure 6

Principal component analysis of log-ratio transformed rare earth element concentrations in samples collected at the centre de Marbaix (A) and rare earth element relationship (Ce/Eu vs La/Lu; B).
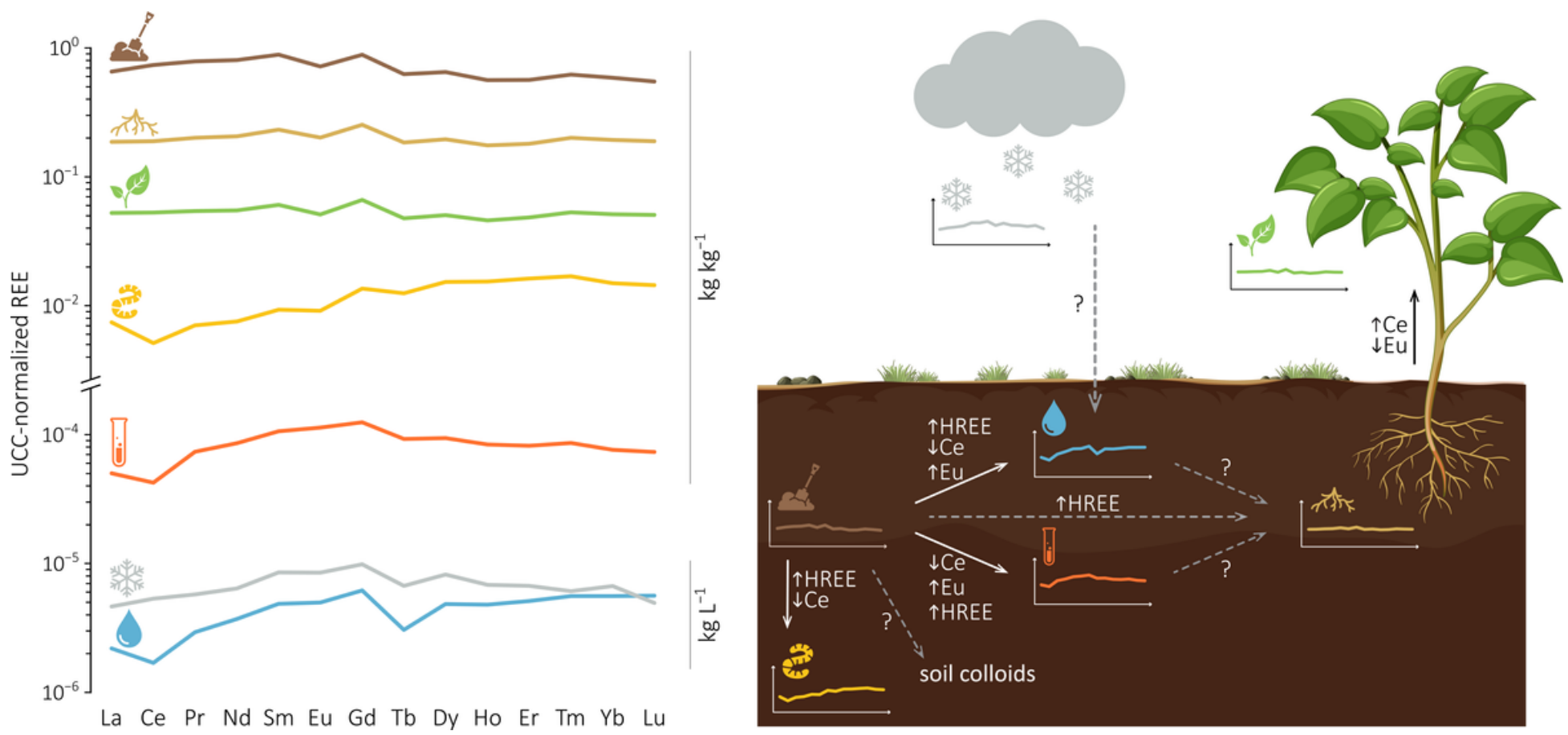

Figure 7

Synthesis of rare earth element (REE) transfer in an intercropping cover crop soil-plant system. 

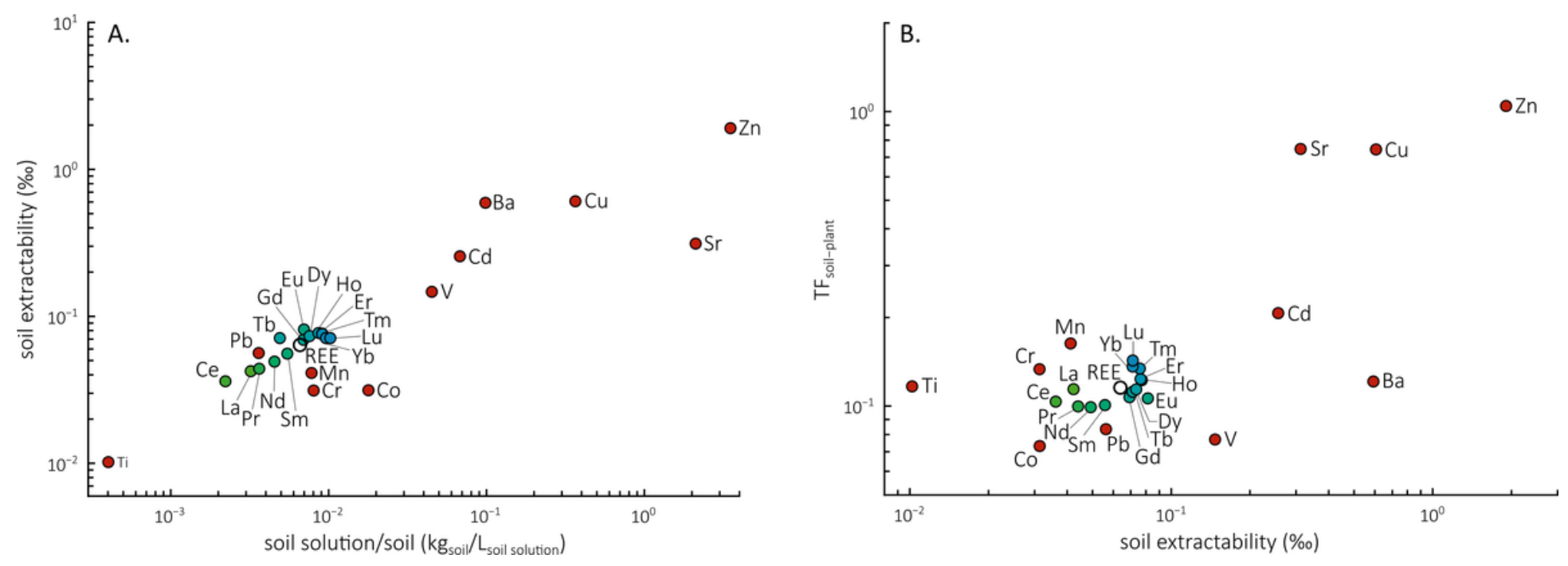

Figure 8

Relationship between soil extractability (soil water-extract/soil concentration ratio, $0-30 \mathrm{~cm}$ soil depth) and soil solution/soil concentration ratio (A) and between soil-plant transfer (TFsoil-plant) and soil extractability (B) of trace elements (red) and rare earth elements (REE, from green for LREE to blue for HREE), as well as the average REE (open circle), in an intercropping cover crop soil-plant system.

\section{Supplementary Files}

This is a list of supplementary files associated with this preprint. Click to download.

- Arbalestrieetal.PlantSoilESM120220202.docx

- Arbalestrieetal.PlantSoilESM220220202.xIsx 